\title{
Anatomy of Mandibular Vital Structures. Part II: Mandibular Incisive Canal, Mental Foramen and Associated Neurovascular Bundles in Relation with Dental Implantology
}

\author{
Gintaras Juodzbalys ${ }^{1}$, Hom-Lay Wang ${ }^{2}$, Gintautas Sabalys ${ }^{1}$ \\ ${ }^{1}$ Department of Oral and Maxillofacial Surgery, Kaunas University of Medicine, Lithuania \\ ${ }^{2}$ Department of Periodontics and Oral Medicine, University of Michigan, Ann Arbor Michigan, USA
}

\author{
Corresponding Author: \\ Gintaras Juodzbalys \\ Vainiku 12 \\ LT- 46383, Kaunas \\ Lithuania \\ Phone: +370 37297055 \\ Fax: +37037323153 \\ E-mail: gintaras@stilusoptimus.lt
}

\begin{abstract}
Objectives: The purpose of the present study was to review the literature of how to identify the mental foramen, mandibular incisive canal and associated neurovascular bundles during implant surgery and how to detect and avoid the damage of these vital structures during implant therapy.

Material and Methods: Literature was selected through a search of PubMed, Embase and Cochrane electronic databases. The keywords used for search were mandibular incisive canal, mental foramen, mental nerve, anterior mental loop. The search was restricted to English language articles, published from 1979 to November 2009. Additionally, a manual search in the major anatomy, dental implant, and periodontal journals and books was performed.

Results: In total, 47 literature sources were obtained and reviewed. The morphology and variations of the mandibular incisive canal, mental foramen and associated neurovascular bundles were presented as two entities. It suggested that clinicians should carefully assess these vital structures to avoid nerve/artery damage.

Conclusions: The mandibular incisive canal, mental foramen and associated neurovascular bundles exist in different locations and possess many variations. Individual, gender, age, race, assessing technique used and degree of edentulous alveolar bone atrophy largely influence these variations. It suggests that the clinicians should carefully identify these anatomical landmarks, by analyzing all influencing factors, prior to their implant surgical operation.
\end{abstract}

Keywords: mandible; chin; alveolar nerve, inferior; anatomy, cross-sectional; radiography; dental implants.

Accepted for publication: 22 December 2009

To cite this article:

Juodzbalys G, Wang HL, Sabalys G. Anatomy of Mandibular Vital Structures. Part II: Mandibular Incisive Canal, Mental Foramen and Associated Neurovascular Bundles in Relation with Dental Implantology.

J Oral Maxillofac Res 2010 (Jan-Mar);1(1):e3

URL: http://www.ejomr.org/JOMR/archives/2010/1/e3/e3ht.pdf

doi: $10.5037 /$ jomr.2010.1103 


\section{INTRODUCTION}

One of the most difficult but usually inadvertently complications which can occur during implant placement in anterior mandible is neurosensory alterations in the chin and lower lip. This complication can occur if important vital structures such as mental foramen (MF) and anterior mental loop are not properly identified and protected [1]. For instance, MF has many anatomical variations not only in its size and shape but also its location and direction of the opening [2-4]. In addition, the mental nerve (MN) may also extend beyond the MF boundary as an intraosseous anterior loop (AL) [5]. Consequently, to avoid damage to these vital structures the exact localization of the anatomical structures should be identified prior to surgery using appropriate radiographic techniques [ㅁ,ㄱ] . Hence, the purpose of this paper was to review the literature related to determination of the topographic anatomy of the mental foramen, mandibular incisive canal and associated neurovascular bundles.

\section{MATERIAL AND METHODS}

Literature was selected through a search of PubMed, Embase and Cochrane Central Register electronic databases. The keywords used for search were mandibular incisive canal, mental foramen, mental nerve, anterior mental loop. The search was restricted to English language articles, published from 1979 to November 2009. Additionally, a manual search in the major anatomy, dental implant, prosthetic and periodontal journals and books was performed. The included publications were clinical and human anatomy studies. To make it easier for readers, the morphology and variations of the mandibular incisive canal and mental foramen and associated neurovascular bundles were presented as two entities.

\section{Mandibular incisive canal (MIC)}

Some authors found a true mandibular incisive canal (MIC), which is a continuation of the mandibular canal [8-11] (Figures 1 and 2). In some cases neurovascular bundles may run through intertrabecular spaces of chin cancellous bone [10]. Obradovic et al. [ $\underline{8}]$ examined 105 cadavers' mandibles and stated the presence of a clearly defined MIC mesially from the MF in $92 \%$ of the 70 dentate mandibles, but only in $31 \%$ of the 30 edentulous ones. The diameter of the canal ranged from $0.48 \mathrm{~mm}$ to $2.9 \mathrm{~mm}$. Mraiwa et al. [10] examined 50 cadavers' mandibles and concluded that MIC

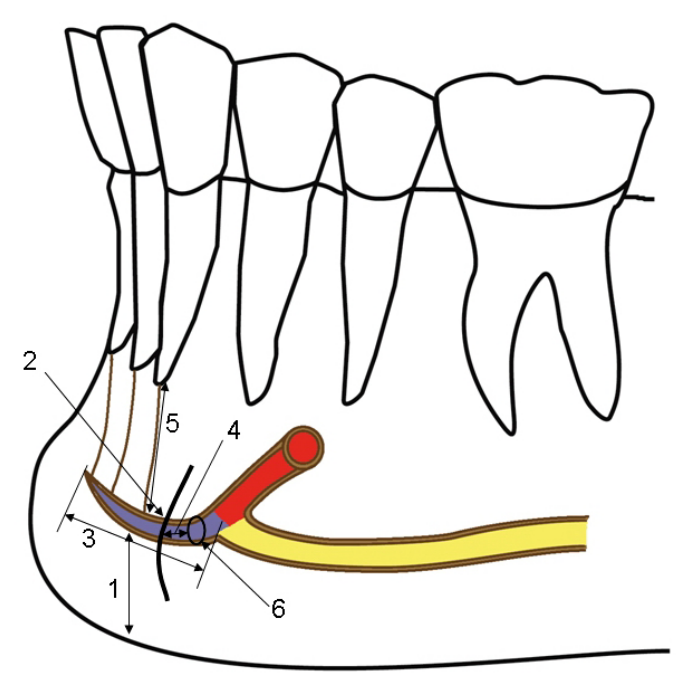

Figure 1. Anatomical variations and position of mandibular incisive canal (MIC).

Colours: blue $=$ MIC, red $=$ mental canal (the anterior opening of the mandibular canal) yellow $=$ mandibular canal.

$1=$ distance from the inferior border of the mandible to the canal ( 7.2 to $10.2 \mathrm{~mm}$ ); 2 = MIC has complete, partial, or no bony cortical borders; $3=$ MIC is terminating apically to the lateral incisor and sometimes apically to the central incisor (approximate length $7 \mathrm{~mm}$ ); $4=$ distance to the buccal plate (approximate distance $2.4 \mathrm{~mm}$ ); 5 $=$ tooth apex-canal distance (in dentate subjects) (approximate distance $5.3 \mathrm{~mm}$ ); 6 = MIC diameter $(0.48$ to $6.6 \mathrm{~mm}$ ).

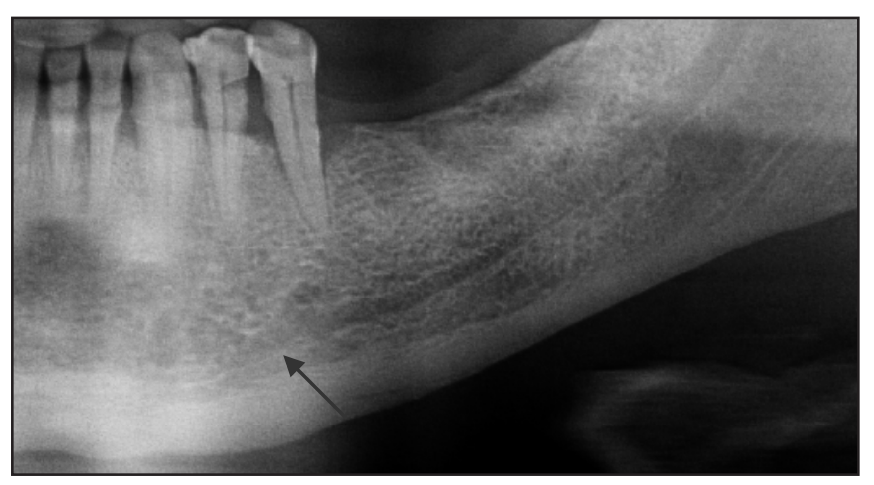

Figure 2. Panoramic radiograph showing mandibular incisive canal (arrow).

was macroscopically observed in $96 \%$ of mandibles and mean (SD) of inner diameter was $1.8(0.5 \mathrm{~mm})$. The MIC was located on average $9.7 \mathrm{~mm}$ (SD $1.8 \mathrm{~mm}$ ) from the lower cortical border and continued towards the incisor region in a slightly downward direction, with a mean (SD) distance to the lower cortical border of $7.2(2.1) \mathrm{mm}$. The canal was narrowing crossing to the midline and only reached the midline in $18 \%$ of cases. The MIC was terminating apically to the lateral incisor and sometimes apically to the central incisor. Jacobs et al. [11] examined 230 spiral computed tomography (CT) scans taken for preoperative planning of implant placement in the posterior mandible. The MIC was identified in $93 \%$ of the cases, with good visibility in $22 \%$ of the cases. Mean (SD) vertical diameter, 
buccolingual diameter, and inner diameter of the MIC were 4.7 (1.1), $3.7(0.7)$, and $1.1(0.3) \mathrm{mm}$ respectively. Uchida et al. [12] measured the diameter of the MIC at its origin and at $1 \mathrm{~mm}$ intervals up to $5 \mathrm{~mm}$ mesially from the origin using operative callipers on 38 cadavers (75 hemimandibles). Measured data were expressed as minimum, maximum, and mean \pm standard deviation: $1.0,6.6$, and $3.1 \pm 1.2 \mathrm{~mm}$ at the origin, $0.6,5.8$, and $2.6 \pm 1.1 \mathrm{~mm}$ at $1 \mathrm{~mm}, 0.5,5.7$, and $2.2 \pm 1.0 \mathrm{~mm}$ at 2 $\mathrm{mm}, 0.5,6.0$, and $2.0 \pm 1.0 \mathrm{~mm}$ at $3 \mathrm{~mm}, 0.5,5.0$, and $1.8 \pm 0.8 \mathrm{~mm}$ at $4 \mathrm{~mm}$, and $0.5,4.9$, and $1.7 \pm 0.8 \mathrm{~mm}$ at $5 \mathrm{~mm}$ mesially. In 2009, Uchida with co-authors [13] reconfirmed their results using $\mathrm{CBCT}$ in 4 cadavers and anatomy in 71 cadavers' mandibles. They found that the MIC diameter ranged from 1.0 to $6.6 \mathrm{~mm}$ with SD of $2.8 \pm 1.0 \mathrm{~mm}$.

Mardinger et al. [14] defined the anatomic and radiographic courses of the MIC in 46 cadavers' hemimandibles and distinguished the canals with complete $(n=10)$, partial $(n=27)$, or no $(n=9)$ bony cortical borders. Furthermore, the canal was either well defined $(\mathrm{n}=11,24 \%)$, poorly defined $(\mathrm{n}=15,32 \%)$, or undetectable $(\mathrm{n}=20,44 \%)$ using conventional radiography. It was concluded that statistically significant correlation was found between the anatomic structure of the MIC bony borders and its radiographic detectability $(\mathrm{P}=0.043)$. Jacobs with co-workers [15] reported that the MIC was identified only in $15 \%$ of the 545 panoramic radiographs, with good visibility in only $1 \%$. In contrast, canal was observed on $93 \%$ of CT scans. Pires et al. [16] showed that all MIC parameters are better determined by cone beam computed tomography (CBCT) imaging than by panoramic radiography. Thus even $83 \%$ of the CBCT scans $(n=89)$ showed the presence of the MIC, as did only $11 \%$ of the panoramic

Table 1. Occurrence and inner diameter of the mandibular incisive canal depending on examination method

\begin{tabular}{lcccc}
\hline \multicolumn{1}{c}{ Study } & $\begin{array}{c}\text { Examination } \\
\text { method }\end{array}$ & N & $\begin{array}{c}\text { Occurance } \\
\mathbf{( \% )}\end{array}$ & $\begin{array}{c}\text { MIC diameter } \\
\text { (mm) }\end{array}$ \\
\hline Obradovic et al. (1993) & $\mathrm{CS}$ & 105 & $\begin{array}{c}92 \text { in dentate mandibles } \\
31 \text { in edentulous }\end{array}$ & $\begin{array}{c}\text { Range } \\
0.48-2.9\end{array}$ \\
\hline Mardinger et al. (2000) & $\mathrm{CS}$ & 46 & 26 & - \\
\hline Mraiwa et al. (2003) & $\mathrm{CS}$ & 50 & 96 & 1.8 (SD 0.5) \\
\hline Jacobs et al. (2002) & $\mathrm{CT}$ & 230 & 93 & 1.1 (SD 0.3) \\
\hline Jacobs et al. (2004) & $\mathrm{PR}$ & 545 & 15 & - \\
\hline Uchida et al. (2007) & $\mathrm{CS}$ & 38 & 100 & $\begin{array}{c}\text { Range } \\
0.5-6.6\end{array}$ \\
\hline Uchida et al. (2009) & $\mathrm{CS}$ & 71 & 100 & $\begin{array}{c}\text { Range } \\
1.0-6.6\end{array}$ \\
\hline Pires et al. (2009) & $\mathrm{CBCT}$ & 4 & 100 & $\begin{array}{c}\text { Range } \\
0.4-4.6\end{array}$ \\
\hline
\end{tabular}

MIC = mandibular incisive canal; $\mathrm{CS}=$ cadaver study; $\mathrm{PR}=$ panoramic radiographs; $\mathrm{CT}=$ computed tomography; $\mathrm{CBCT}=$ cone beam computed tomography. radiographs. The range of the MIC diameter was from $0.4 \times 0.4 \mathrm{~mm}$ to $4.6 \times 3.2 \mathrm{~mm}$. The mean length of the canal was $7 \pm 3.8 \mathrm{~mm}$. The distance from the inferior border of the mandible to the canal was $10.2 \pm 2.4 \mathrm{~mm}$, and the mean distance to the buccal plate was $2.4 \mathrm{~mm}$. The apex-canal distance (in dentate subjects) was 5.3 $\mathrm{mm}$. Therefore, it is recommended to use conventional tomographs or CBCT images for better imaging of the intermental foramen area. Occurrence and diameter of the incisive canal depending on examination method are summarized in Table 1.

In case of large MIC, a patient can experience discomfort during osteotomy development precluding implant placement or experience postoperative pain requiring implant removal [17].

\section{Mandibular incisive nerve (MIN)}

Mardinger et al. [18] studied the MIC in 46 cadavers' hemimandibles and found that a mandibular incisive neurovascular bundle was anatomically found in all specimens, travelling within the canal. De Andrade with co-authors [9] concluded that, the MIN is a normal structure that typically extends closer to the mandibular midline. The incisive nerve supplies innervation to first bicuspid, canine, and lateral and central incisors.

\section{Mental foramen (MF)}

The size, shape, location and direction of the opening of the MF have many variations and these variations are related to race and even gender (Figure 3). Neiva et al. [2] found that the mean height of the MF was 3.47 $\pm 0.71 \mathrm{~mm}$ (range 2.5 to $5.5 \mathrm{~mm}$ ) and the mean width was $3.59 \pm 0.8 \mathrm{~mm}$ (range 2 to $5.5 \mathrm{~mm}$ ) after measuring 22 Caucasian skulls. Apinhasmit et al. [3] examined 106 Thai adult skulls and found that mean MF width was $2.80 \pm 0.70 \mathrm{~mm}$. Gershenson et al. [4] studied 525 dry mandibles and 50 cadaver dissections and found that MF shape was round in $34.48 \%$ of cases with an average diameter of $1.68 \mathrm{~mm}$ and oval in $65.52 \%$ with an average long diameter of $2.37 \mathrm{~mm}$. Yosue and Brooks [19] the appearance of the MF on panoramic radiographs classified as a continuous, separated, diffuse, or unidentified type (Figure 4). In a sample of 297 patients, the most frequent appearance was separated (43\%), 
followed by diffuse (24\%), continuous $(21 \%)$, and unidentified $(12 \%)$. The mean diameter of the foramen was stated at $3.5 \mathrm{~mm}$ width. Mbajiorgu et al. [20] found different shapes of the MF in the 32 mandibles of adult Black Zimbabweans: round and oval in 14 of 32 $(43.8 \%)$ and 18 of $32(56.3 \%)$ mandibles respectivelly. Igbigbi and Lebona [21] from study on 70 Malawian mandibles concluded that the majority of MF was oval in shape. In black Tanzanian individuals, the shape of the MF was oval in $54 \%$ and rounded in $46 \%$ [22]. In Jordanian population, the majority of foramina were round in shape [23].

The location of the MF differs in the horizontal and vertical planes. The most popular method for identification of MF was proposed by Fishel et al. [24] and Green [25]. The horizontal position of the MF was recorded as either in line with the longitudinal axis of a tooth or as lying between the two teeth (Figure 3). Fishel et al. [24] investigated vertical MF position and reported that in the first premolar area of 936 patients, the MF was situated coronal to the apex in $38.6 \%$ of cases, at the apex in $15.4 \%$ of cases, and apical to the apex in $46.0 \%$ of cases. The MF location, in relation to the second premolar, was coronal to the apex in $24.5 \%$ of cases, at the apex in $13.9 \%$ of cases, and apical to the apex in $61.6 \%$ of cases (Figure 5). Consequently, placement of immediate implants in the premolar area is associated with possible complications, because in $25 \%$ to $38 \%$ of cases the foramen is located coronal to the premolars apex [24]. Table 2 summarized the mental foramen's location in the horizontal and vertical plane. It is evident from these studies that location of MF is related with race. For example, the position of the MF in the Mongoloid population was in line with the longitudinal axis of second lower premolar. Their positions in Caucasoid samples were just mesial to those in Chinese, Melanesian, Asian Indians, Thai, Korean, Saudi and Tanzanian samples. It is very unusual to find foramen located anteriorly by the canine or posteriorly beyond the first molar (Table 2).

In some studies, another anatomical landmark such as distance form the midline of the mandible for MF location identification was recorded (Figure 3). Agthong et al. [26] indicated the foramen $28 \mathrm{~mm}$ from the midline of the mandible and 14 to $15 \mathrm{~mm}$ from the inferior border of the mandible. Neiva et al. [2] found that distance from MF to the midline was $27.61 \pm 2.29 \mathrm{~mm}$, and from

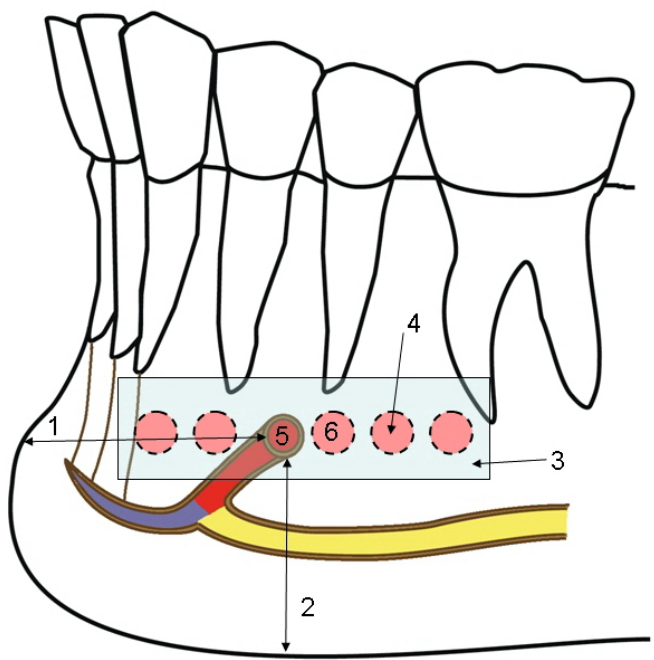

Figure 3. Anatomical variations of the mental foramen (MF) position in the horizontal plane in relation to the roots of teeth. Colours: blue $=$ MIC, red = mental canal (the anterior opening of the mandibular canal) yellow $=$ mandibular canal.

1 = distance from MF to midline of the mandible (approximate distance $28 \mathrm{~mm}$ ); 2 = distance from MF to the inferior border of the mandible (14 to $15 \mathrm{~mm}) ; 3=$ possible MF location zone in the horizontal plane in relation to the roots of teeth; $4=$ the shape of MF can be round or oval, the diameter is 1.68 to $3.5 \mathrm{~mm} ; 5=$ prevalence location of MF in the horizontal plane for Caucasian population; 6 $=$ prevalence location of MF in the horizontal plane for Mongoloids and African people.
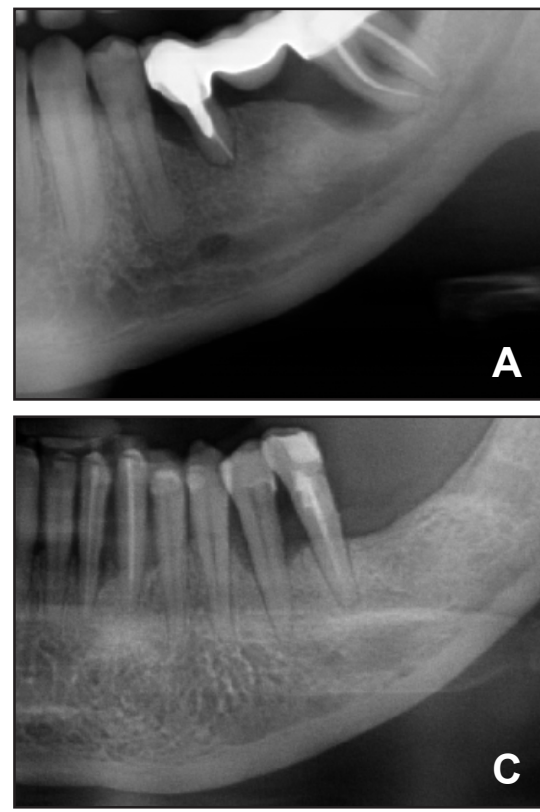

Figure 4. The appearance of the mental foramen on panoramic radiographs: classification by Yosue and Brooks [18]. A = continuous; $\mathrm{B}=$ separated; $\mathrm{C}=$ diffuse; $\mathrm{D}=$ unidentified type. 

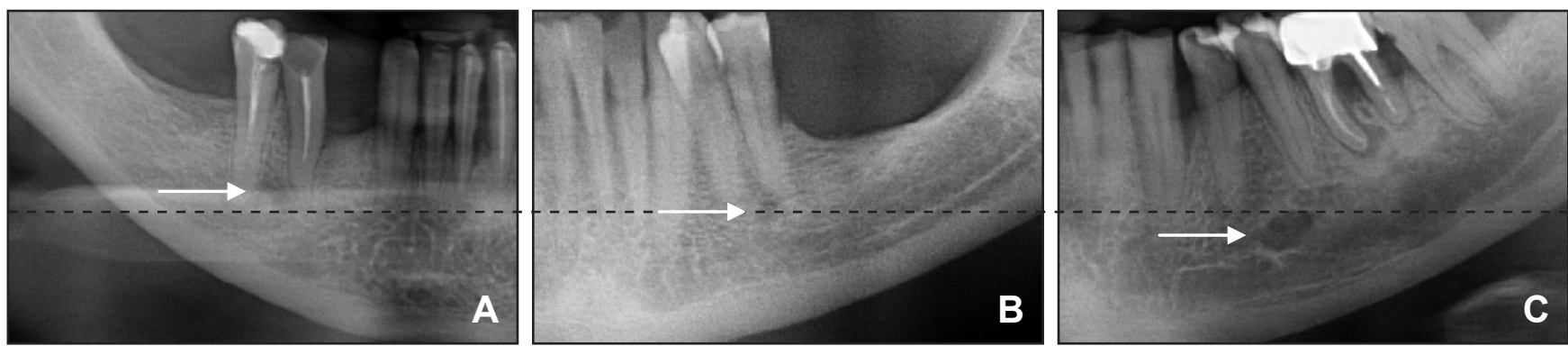

Figure 5. Panoramic radiographs showing variations of the mental foramen (MF) position in the vertical plane in relation to premolars apex: classification by Fishel et al. [24]. A = the MF situated coronal to the apex; B = the MF situated at the apex; $\mathrm{C}=$ the $\mathrm{MF}$ situated apical to the apex.

It has been reported that the average distance between the cusp tip and the superior border of the MF was $23.42 \mathrm{~mm}$ in direct measurement and $25.69 \mathrm{~mm}$ in the panoramic assessment [6]. The mean distance between the superior border of the MF and the bottom of the mandible was $14.33 \mathrm{~mm}$ by direct measurement and $16.52 \mathrm{~mm}$ by radiographic measurement.

Song with co-authors [27] measured the MF location based on soft-tissue landmarks and stated that MF was located $20.4 \pm 3.9 \mathrm{~mm}$ inferior and $3.3 \pm$ $2.9 \mathrm{~mm}$ medial to the cheilions. The distance between the cheilions and MF was $20.9 \pm 3.8 \mathrm{~mm}$, and the vertical angle between these structures was $9.2 \pm 8.1$ degrees inferomedially. Some authors are using crest of mandibular alveolar bone as anatomical landmark. However, this landmark is not stable because different levels of crestal bone loss existed [10]. For example, after extraction of teeth and resorption of alveolar bone, the MF is closer to the alveolar crest [4]. In extreme degrees of resorption, the MF and the final part of the inferior alveolar nerve were found in the surface of the bone and directly under the gums. Ulm et al. [28] found in 43 edentulous, lower jaw halves that the distance between the canal and the atrophic alveolar ridge being affected more strongly than that between the canal and the base of the mandible.

Solar et al. [29] observed that the mental canal (the anterior opening of the mandibular canal) traverses cranially at an angle of inclination ranging from $11^{\circ}$ to $77^{\circ}$. They noted that the average gradient in 37 specimens (22 had an anterior loop) was $50^{\circ}$. Kieser et al. [30] classified the path of emergence of MF into posterior, anterior, right-angled or multiple. They investigated the path of emergence of the mental canal and $\mathrm{MN}$ in a number of human population groups. Skeletal material comprised 117 Negro skulls (53 males), 114 Caucasoid skulls (62 males) and 100 pre-contact Maori skulls (70 males). The most common pattern of emergence in

Table 2. Locations of the mental foramen in horizontal (percentage of occurrence) and vertical plane

\begin{tabular}{|c|c|c|c|c|c|c|}
\hline \multirow[b]{2}{*}{ Study } & \multirow[b]{2}{*}{ Population } & \multirow[b]{2}{*}{$\mathbf{N}$} & \multicolumn{3}{|c|}{ Horizontal plane } & \multirow[b]{2}{*}{ Vertical plane } \\
\hline & & & $\begin{array}{l}\text { Apical to second } \\
\text { premolar }\end{array}$ & $\begin{array}{c}\text { Between apices } \\
\text { of premolars }\end{array}$ & Other location & \\
\hline Fishel et al. (1976) & Caucasian & 1000 & 18.9 & 70.4 & $\begin{array}{l}\text { Apex first premolar: } 3.3 \\
\text { Mesial to first premolar: } 1.5 \\
\text { Between premolar/molar: } 6.6 \\
\text { By the molar: } 1\end{array}$ & Superior to the level of the apices of the premolars \\
\hline Wang et al. (1986) & Chinese & 100 & 59 & 21 & $\begin{array}{l}\text { Between premolars/molars: } 19 \mathrm{I} \\
\text { By the molar: } 1\end{array}$ & $\begin{array}{l}\text { Distance between superior border of the MF and the } \\
\text { bottom of the lower second premolar socket: } 2.50 \mathrm{~mm}\end{array}$ \\
\hline Kekere-Ekun (1989) & Nigerian & 604 & 55.63 & 26.99 & $\begin{array}{l}\text { Mesial to first premolar: } 0.17 \\
\text { Apex first premolar: } 1.66 \\
\text { Between premolar/molars: } 12.3 \\
\text { By the molar: } 3.3\end{array}$ & Not measured \\
\hline Shankland (1994) & Asian Indians & 138 & 75.4 & 5.8 & $\begin{array}{l}\text { Between premolar/molars: } 14.5 \\
\text { By the molar: } 4.3\end{array}$ & Not measured \\
\hline al Jasser and Nwoku (1998) & Saudi & 414 & 45.3 & 42.7 & Not measured & Not measured \\
\hline Ngeow and Yuzawati (2003) & Malay & 169 & 69.2 & 19.6 & $\begin{array}{l}\text { Apex first premolar: } 3.4 \\
\text { Between premolar/molar: } 6.6 \\
\text { By the molar: } 1\end{array}$ & Not measured \\
\hline Neiva et al. (2004) & Caucasian & 22 & 42 & 58 & Not measured & Distance between MF and CEJ of teeth: $15.52 \pm 2.37 \mathrm{~mm}$ \\
\hline Apinhasmit et al. (2006) & Thai & 106 & 56.9 & 28.7 & $\begin{array}{l}\text { Between premolar/molar: } 10.2 \\
\text { Apex first premolar: } 3 \\
\text { By the molar: } 1.2\end{array}$ & Not measured \\
\hline Kim et al. (2006) & Korean & 72 & 64.3 & 26.8 & Apex first premolar: 8.9 & $\begin{array}{l}\text { Distance between the cusp tip and the superior border of } \\
\text { the mental foramen: } 23.42 \mathrm{~mm}\end{array}$ \\
\hline Fabian (2007) & Tanzanian & 100 & 45 & 12 & $\begin{array}{l}\text { Between premolar/molar: } 35 \\
\text { By the molar: } 8\end{array}$ & Not measured \\
\hline $\begin{array}{l}\text { Haghanifar and Rokouei } \\
\text { (2009) }\end{array}$ & Iranian & 400 & 46 & 47.2 & $\begin{array}{l}\text { Between premolar/molar: } 5.3 \\
\text { By the molar: } 1.5\end{array}$ & Not measured \\
\hline
\end{tabular}


Caucasoid and Maori was a posterior direction $(86.7 \%$ of Caucasoid males, $90.2 \%$ of Caucasoid females; $85.5 \%$ of Maori males, $93.1 \%$ of Maori females). In Black, the most common pattern was a right-angled path of emergence ( $45.8 \%$ of males, $45.0 \%$ of females). Igbigbi and Lebona [21] from their study on 70 Malawian population mandibles and Apinhasmit et al. [3] from study of 106 Thai individual's mandibles, recorded usual direction of MF opening having posterosuperior direction. Fabian [22] from measurements of 100 Tanzanian mandibles concluded that the direction of MF opening was superiorly in $44 \%$, posterosuperiorly in $40 \%$, labially in $10 \%$, mesially (anteriorly) in $3 \%$, and posteriorly in 3\% of cases (Figure 6).

More than one MF may be present and probably it is also related with race. Sawyer et al. [31] assessed the frequency of accessory MF in skulls in four population groups: 20th century Asian Indians, African Americans and American Whites, and pre-Columbian Nazca Indians. Accessory MF were found less frequently in the American White and Asian Indian populations than in the other groups: American Whites $=1.4 \%$; Asian Indians $=1.5 \%$; African Americans $=5.7 \%$; and preColumbian Nazca Indians $=9.0 \%$.

Shankland [32] showed that $6.62 \%$ of the Asian Indians (from 138 mandibles) possessed accessory MF. Al-Khateeb [23] observed accessory MF in 10\% of the 860 panoramic radiographs obtained from Jordanian populations. Katakami et al. [33] diagnosed 17 accessory mental foramina's in 16 patients using limited CBCT for 150 patients. Accessory MF tended to exist in the apical area of the first molar and posterior or inferior area of the MF. The accessory branches of the mandibular canal showed common characteristics in the course of gently sloping posterosuperior direction in the buccal surface area. Similarly, Naitoh et al. [34] studied 157 patients CBCT images and found the accessory MF observed in $7 \%$ of patients. There was no significant difference regarding the sizes of the MF between accessory MF presence and absence. Also, the mean distance between the mental and accessory MF was $6.3 \mathrm{~mm}$ (SD $1.5 \mathrm{~mm}$ ). In contrast, de Freitas et al. [35] found no MF in 2 skulls: among 1,435 dry human mandibles, the foramen was absent twice on the right side $(0.06 \%)$ and once on the left side $(0.03 \%)$.

\section{Mental nerve (MN) and anterior loop (AL) of the mental nerve}

Larger terminal branch of inferior alveolar nerve emerges from the MF as the mental nerve. Usually three nerve branches of approximately $1 \mathrm{~mm}$ in diameter come out of the MF [10]. Some authors reported presence of accessory branches of $\mathrm{MN}$ and this is
A

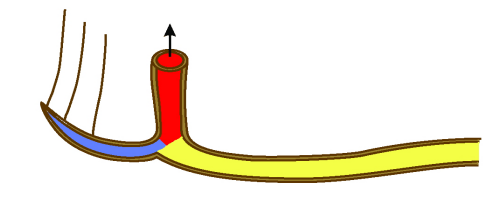

B
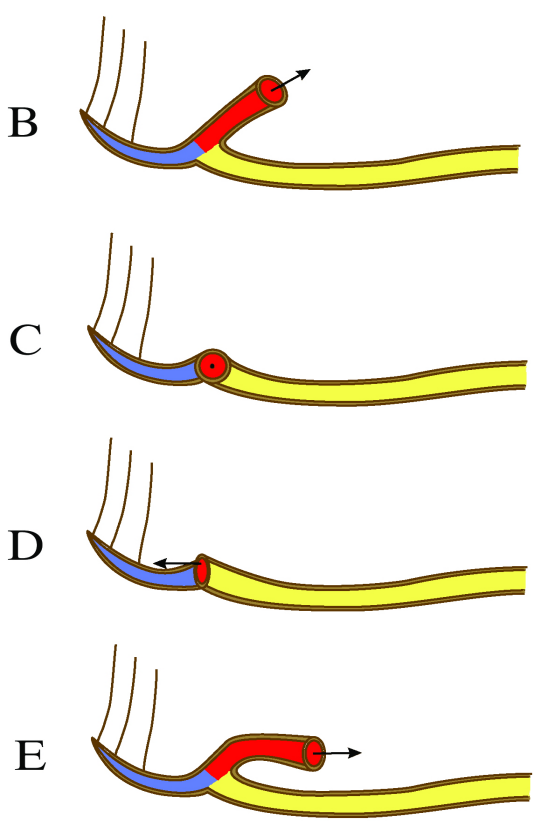

Figure 6. Emergence patterns of the mental canal and mental foramen opening.

Colours: blue $=\mathrm{MIC}$, red $=$ mental canal (the anterior opening of the mandibular canal) yellow $=$ mandibular canal.

$\mathrm{A}=$ superiorly, $\mathrm{B}=$ posterosuperiorly; $\mathrm{C}=$ labially; $\mathrm{D}=$ mesially (anteriorly); $\mathrm{E}=$ posteriorly.

related with presence of accessory MF (see above). Hu and co-workers [36] investigated the topography of the MN by dissecting 31 hemifaces of Korean cadavers and divided this nerve based on the distribution area of the $\mathrm{MN}$ as follows: angular, medial inferior labial, lateral inferior labial and mental branches. In most cases lateral inferior labial branch is separating from the angular branch. Previously, Alantar et al. [37] studied $32 \mathrm{MN}$ dissections in 16 cadavers and found the mean number of lower labial branches was 2 (range 1 to 4 ).

Pogrel with co-workers [38] tested the hypothesis that some sensory innervation to the lower incisor teeth comes from re-entry of the terminal branches of the MN through the labial plate of the anterior mandible. They investigated 10 cadaver's heads and concluded: three of $20(15 \%)$ specimens showed unequivocal evidence of nerve re-entry into the labial plate. Five specimens displayed strong evidence of nerve fibers re-entering the plate, but these were too fragile to be dissected through the periosteum without breaking. In 12 of $20(60 \%)$ specimens, there were no branches identified that re-entered the bone plate. Of the 8 specimens showing evidence of re-entry, 4 had substantial midline crossover. The finding that branches of the MN may re-enter the labial plate to supply the 
lower incisors explains the phenomenon of crossover innervation from the contralateral $\mathrm{MN}$.

When inferior alveolar nerve arises from the mandibular canal and runs outward, upward and backward to open at the MF it was referred as anterior loop [39] (Figures 7 and 8). A more precise description was reported by Bavitz [40] and Misch [41]: "where the mental neurovascular bundle crosses inferior and anterior to the MF then doubles or loops back to exit the MF". Kuzmanovic [42] with co-authors described it as the anterior loop of mental nerve. Jalbout and Tabourian [5] described AL as "an extension of the inferior alveolar nerve, anterior to the MF, prior to exiting the canal." This means that the MN, however, may extend beyond the MF boundary as an intraosseous anterior loop. Solar et al. [29] detected an AL in 60\% (22 of 37 ) of dissected cadaver mandibles, ranging in length from 0.5 to $5 \mathrm{~mm}$ (mean $1 \mathrm{~mm}$ ). Neiva et al. [2] were probing the mesial cortical wall of the mental canal in 22 cadavers and reported the AL was present $88 \%$ of the time and its length ranged from 1 to $11 \mathrm{~mm}$ (mean $4.13 \mathrm{~mm}$ ). Rosenquist [43] detected AL in 24\% (15 of 58) of cadaveric mandibles with loop length variations from 0 to $1 \mathrm{~mm}$. In 13 cadavers, the loop was $0.5 \mathrm{~mm}$ long, and two patients had a $1 \mathrm{~mm}$ length loop (mean $0.15 \mathrm{~mm}$ ). Similarly, Keiser [44] found that there was no measurable $\mathrm{AL}$ after exposing $1 \mathrm{~cm}$ of the nerve on both sides of the MF in 56 cadaveric mandibles.

Anterior mental loop assessment using radiographic methods revealed large variations. Yosue and Brooks [19] noted that an AL (termed continuous type MF in their study) was present in $21 \%$ of the 297 radiographs studied. Misch and Crawford [45] noted an AL whose average length was $5 \mathrm{~mm}$ in $12 \%$ of 324 patient's panoramic radiographs. Arzouman et al. [39] assessed 25 adult skulls using two panoramic machines both with and without radiopaque markers placed into the mandibular canal and AL. The AL was also measured directly using flexible tubing $(2 \mathrm{~mm}$ in diameter). Significantly fewer loops were detected in radiographs as compared with anatomic assessment $(\mathrm{P}<0.001)$. A significant loop $(>2 \mathrm{~mm})$ was identified in $92 \%$ to $96 \%$ of the direct measurements, whereas radiographs identified only $56 \%$ and $76 \%$ using different panoramic machines. The average length of the AL based on direct measurements was $6.95 \mathrm{~mm}$, whereas radiographic measurements were $3.18 \mathrm{~mm}$ and $3.45 \mathrm{~mm}$ using different panoramic machine. Jacobs et al. [15] examined 230 spiral CT scans taken for preoperative planning of implant placement in the posterior mandible where the AL appeared in $7 \%$ of cases. Later Jacobs with co-workers [11] examined 545 patient's panoramic radiographs and found an $\mathrm{AL}$ in $11 \%$ of cases, but was well visualized in only $3 \%$ of

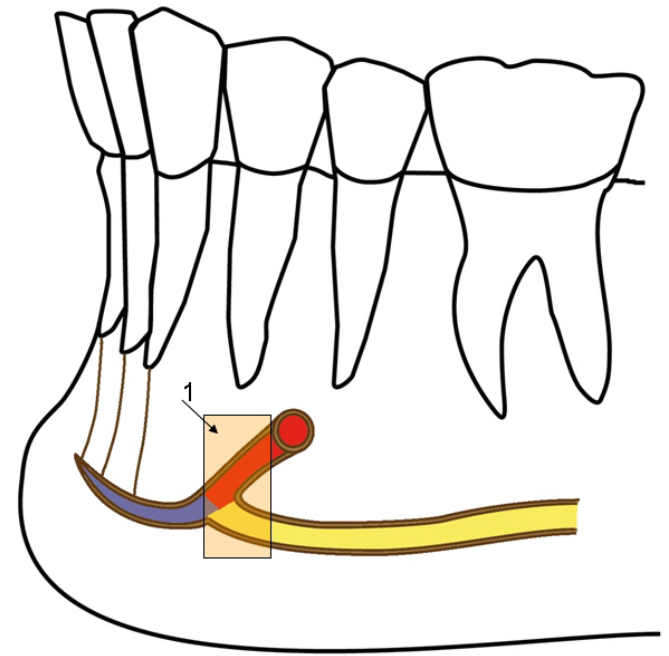

Figure 7. The anterior loop (AL) of the mental nerve: length variations from the most anterior loop point to mental foramen. Colours: blue $=\mathrm{MIC}$, red $=$ mental canal (the anterior opening of the mandibular canal) yellow $=$ mandibular canal.

$1=$ length of the AL (0.00 to $10 \mathrm{~mm})$.

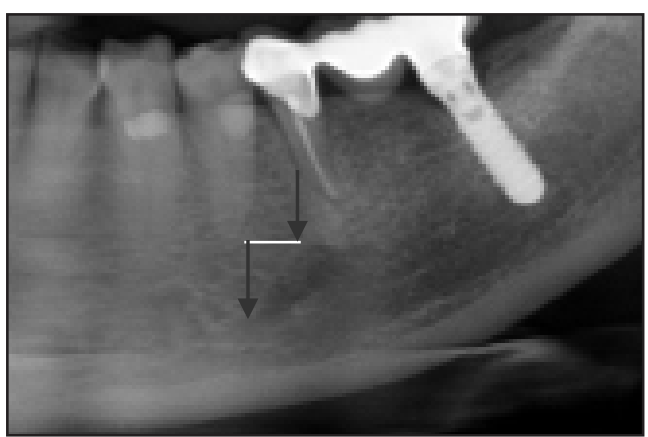

Figure 8. Panoramic radiograph showing extension of the mental nerve beyond the mental foramen boundary as an intraosseous anterior loop (arrows).

detected loops. Study was undertaken by Ngeow et al. [46] to determine AL visibility on 97 dental panoramic radiographs in dentate subjects of various age groups. The AL was visible in $39(40.2 \%)$ dental panoramic radiographs encompassing 66 sites (34.4\%). Anterior loops were most often observed bilaterally, followed by on the right side only. The visibility of AL was reduced as the age of the subjects increased. No relationship was found between subject gender and the pattern of visualization of the AL. Authors then concluded that panoramic radiography is not sufficient for presurgical implant planning in the mental region and may need to be supplemented with other modalities such as CT for better visualization of the area.

Investigations that compared radiographic and cadaveric dissection data with respect to identifying the $\mathrm{AL}$ reported that radiographic assessments result in a high percentage of false-positive and false-negative findings $[\underline{14}, \underline{39}, \underline{40}, \underline{42}]$. Varied results may be attributed to different criteria used to define the $\mathrm{AL}$, dissimilar 
diagnostic techniques, and diverse findings in patients [47]. For example, in above mentioned study of Arzouman et al. [39] a significant loop (>2 mm) was identified in $92 \%$ to $96 \%$ of the direct measurements, whereas radiographs identified only $56 \%$ and $76 \%$ using different panoramic machines. This can be explained by the finding that distance bone markers or tubing that penetrates the MF (on dry skulls) cannot reliably be used to indicate the length of the AL because these devices may penetrate into the MIC $[42,43]$. Bavitz et al. [40] reported the $\mathrm{AL}$ was present in $54 \%$ (17 of 35 ) of periapical radiographs taken of hemimandibles. However, this finding was only confirmed by dissection in $11 \%$ (four of 35 ) of the corresponding cadaver specimens. Loop sizes ranged from 0.0 to $7.5 \mathrm{~mm}$ on periapical radiographs and from 0 to $1.0 \mathrm{~mm}$ among cadaver specimens. They concluded that damage to the MN can be avoided if the distal surface of the most posterior implant is $1 \mathrm{~mm}$ anterior to the anterior border of the MF. Mardinger et al. [14] assessed 46 hemimandibles using periapical films and dissection with physical evaluation. Anatomically, an AL of the MN was observed in only 13 hemimandibles $(28 \%)$. No correlation was found between the radiographic image and the anatomical shape of the loop. Furthermore, 70\% of the radiographically diagnosed loops, $40 \%$ were not seen in anatomical examination. Anatomically, 8 of the $13 \mathrm{AL}$ were 0.4 to $1 \mathrm{~mm}$ long, 4 of $13 \mathrm{AL}$ were 1.1 to $2 \mathrm{~mm}$, and one AL was $2.19 \mathrm{~mm}$. Thus, $11 \%$ (5 of 46) of AL were $>1 \mathrm{~mm}$. Kuzmanovic et al. [42] studied correlation between the visual interpretation of the panoramic radiographs and the anatomical dissection findings in a 22 cadaveric sample. The $\mathrm{AL}$ of the mental canal was only identified in six panoramic radiographs (27\%) (range $0.5-3 \mathrm{~mm}$ ) and eight $(35 \%)$ anatomical measurements. Authors then concluded that clinicians should not rely on panoramic radiographs for identifying the $\mathrm{AL}$ of the $\mathrm{MN}$ during implant treatment planning. However, a safe guideline of $4 \mathrm{~mm}$, from the most anterior point of the MF, is recommended for implant treatment planning based upon the anatomical findings.

More accurate of AL assessments were obtained by Uchida et al. [13] who used CBCT in 4 cadavers and dissected 71 cadavers. The anatomic measurements revealed mean AL size of $1.9 \pm 1.7 \mathrm{~mm}$ and range 0.0 to $9.0 \mathrm{~mm}$. The average discrepancies between CBCT and anatomic measurements were $0.06 \mathrm{~mm}$ or less.

\section{CONCLUSIONS}

1. The occurrence of the mandibular incisive canal was 11 to $92 \%$ of cases pending the examination method used. Panoramic radiographs have the least accuracy $(11 \%)$ in identifying this structure. Hence, a better image such as conventional tomographs or CT dental scans should be used especially in the intermental foramen area.

2. The mental foramen in the horizontal plane can be located mesial, distal or between apices of roots of premolars. The position in the vertical plane in relation to premolars apex can be situated coronal to the apex, at the apex, or apical to the apex. These variations are influenced by individual, gender, age, race, and assessing technique used.

3. A high percentage of false-positive and falsenegative occurs when diagnosing the anterior loop with radiographs. Clinicians should not rely on panoramic radiographs for identifying the anterior loop of the mental nerve during implant treatment planning. Furthermore, based upon the anatomical findings a safe guideline of $4 \mathrm{~mm}$ from the most anterior point of the MF is recommended for implant treatment planning.

\section{ACKNOWLEDGMENTS AND DISCLOSURE STATEMENTS}

The authors report no conflicts of interest related to this study.

\section{REFERENCES}

1. Walton JN. Altered sensation associated with implants in the anterior mandible: a prospective study. J Prosthet Dent. 2000 Apr;83(4):443-9. [Medline: 10756294] [doi: 10.1016/S0022-3913(00)70039-4]

2. Neiva RF, Gapski R, Wang HL. Morphometric analysis of implant-related anatomy in Caucasian skulls. J Periodontol. 2004 Aug;75(8):1061-7. [Medline: 15455732] [doi: 10.1902/jop.2004.75.8.1061]

3. Apinhasmit W, Chompoopong S, Methathrathip D, Sansuk R, Phetphunphiphat W. Supraorbital Notch/Foramen, Infraorbital Foramen and Mental Foramen in Thais: anthropometric measurements and surgical relevance. J Med Assoc Thai. 2006 May;89(5):675-82. [Medline: 16756055]

4. Gershenson A, Nathan H, Luchansky E. Mental foramen and mental nerve: changes with age. Acta Anat (Basel). 1986;126(1):21-8. [Medline: 3739599] [doi: 10.1159/000146181]

5. Jalbout Z, Tabourian G. Glossary of Implant Dentistry. Upper Montclair, NJ: International Congress of Oral Implantologists; 2004:16. 
6. Kim IS, Kim SG, Kim YK, Kim JD. Position of the mental foramen in a Korean population: a clinical and radiographic study. Implant Dent. 2006 Dec;15(4):404-11. [Medline: 17172959] [doi: 10.1097/01.id.0000243319.66845.15]

7. Rueda S, Gil JA, Pichery R, Alcañiz M. Automatic segmentation of jaw tissues in CT using active appearance models and semi-automatic landmarking. Med Image Comput Comput Assist Interv. 2006;9(Pt 1):167-74. [Medline: 17354887] [doi: $10.1007 / 11866565$ 21]

8. Obradovic O, Todorovic L, Pesic V, Pejkovic B, Vitanovic V. Morphometric analysis of mandibular canal: clinical aspects. Bull Group Int Rech Sci Stomatol Odontol. 1993 Jul-Sep;36(3-4):109-13. [Medline: 8219689]

9. De Andrade E, Otomo-Corgel J, Pucher J, Ranganath KA, St George N Jr. The intraosseous course of the mandibular incisive nerve in the mandibular symphysis. Int J Periodontics Restorative Dent. 2001 Dec;21(6):591-7. [Medline: 11794570$]$

10. Mraiwa N, Jacobs R, Moerman P, Lambrichts I, van Steenberghe D, Quirynen M. Presence and course of the incisive canal in the human mandibular interforaminal region: two-dimensional imaging versus anatomical observations. Surg Radiol Anat. 2003 Nov-Dec;25(5-6):416-23. Epub 2003 Sep 11. [Medline: 13680184] [doi: 10.1007/s00276-003-0152-8]

11. Jacobs R, Mraiwa N, Van Steenberghe D, Sanderink G, Quirynen M. Appearance of the mandibular incisive canal on panoramic radiographs. Surg Radiol Anat. 2004 Aug;26(4):329-33. Epub 2004 Jun 10. [Medline: 15197490] [doi: 10.1007/s00276-004-0242-2]

12. Uchida Y, Yamashita Y, Goto M, Hanihara T. Measurement of anterior loop length for the mandibular canal and diameter of the mandibular incisive canal to avoid nerve damage when installing endosseous implants in the interforaminal region. J Oral Maxillofac Surg. 2007 Sep;65(9):1772-9. [Medline: 17719396] [doi: 10.1016/j.joms.2006.10.015]

13. Uchida Y, Noguchi N, Goto M, Yamashita Y, Hanihara T, Takamori H, Sato I, Kawai T, Yosue T. Measurement of anterior loop length for the mandibular canal and diameter of the mandibular incisive canal to avoid nerve damage when installing endosseous implants in the interforaminal region: a second attempt introducing cone beam computed tomography. J Oral Maxillofac Surg. 2009 Apr;67(4):744-50. [Medline: 19304029] [doi: 10.1016/j.joms.2008.05.352]

14. Mardinger O, Chaushu G, Arensburg B, Taicher S, Kaffe I. Anterior loop of the mental canal: an anatomical-radiologic study. Implant Dent. 2000;9(2):120-5. [Medline: 11307391] [doi: 10.1097/00008505-200009020-00003]

15. Jacobs R, Mraiwa N, vanSteenberghe D, Gijbels F, Quirynen M. Appearance, location, course, and morphology of the mandibular incisive canal: an assessment on spiral CT scan. Dentomaxillofac Radiol. 2002 Sep;31(5):322-7. [Medline: 12203132] [doi: 10.1038/sj.dmfr.4600719]

16. Pires CA, Bissada NF, Becker JJ, Kanawati A, Landers MA. Mandibular Incisive Canal: Cone Beam Computed Tomography. Clin Implant Dent Relat Res. 2009 Aug 6. [Epub ahead of print] [Medline: 19673957] [doi: 10.1111/j.1708-8208.2009.00228.x]

17. Romanos GE, Greenstein G. The incisive canal. Considerations during implant placement: case report and literature review. Int J Oral Maxillofac Implants. 2009 Jul-Aug;24(4):740-5. Review. [Medline: 19885417]

18. Mardinger O, Chaushu G, Arensburg B, Taicher S, Kaffe I. Anatomic and radiologic course of the mandibular incisive canal. Surg Radiol Anat. 2000;22(3-4):157-61 [Medline: 11143307] [doi: 10.1007/s00276-000-0157-5]

19. Yosue T, Brooks SL. The appearance of mental foramina on panoramic radiographs. I. Evaluation of patients. Oral Surg Oral Med Oral Pathol. 1989 Sep;68(3):360-4. [Medline: 2771380] [doi: 10.1016/0030-4220(89)90224-7]

20. Mbajiorgu EF, Mawera G, Asala SA, Zivanovic S. Position of the mental foramen in adult black Zimbabwean mandibles: a clinical anatomical study. Cent Afr J Med. 1998 Feb;44(2):24-30. [Medline: 9675967]

21. Igbigbi PS, Lebona S. The position and dimensions of the mental foramen in adult Malawian mandibles. West Afr J Med. 2005 Jul-Sep;24(3):184-9. [Medline: 16276691]

22. Fabian FM. Position, shape and direction of opening of the mental foramen in dry mandibles of Tanzanian adult black males. Ital J Anat Embryol. 2007 Jul-Sep;112(3):169-77 [Medline: 18078238]

23. Al-Khateeb T, Al-Hadi Hamasha A, Ababneh KT. Position of the mental foramen in a northern regional Jordanian population. Surg Radiol Anat. 2007 Apr;29(3):231-7. Epub 2007 Mar 21. [Medline: 17375258] [doi: 10.1007/s00276-007-0199-z]

24. Fishel D, Buchner A, Hershkowith A, Kaffe I. Roentgenologic study of the mental foramen. Oral Surg Oral Med Oral Pathol. 1976 May;41(5):682-6. [Medline: 1063970] [doi: 10.1016/0030-4220(76)90325-X]

25. Green RM. The position of the mental foramen: a comparison between the southern (Hong Kong) Chinese and other ethnic and racial groups. Oral Surg Oral Med Oral Pathol. 1987 Mar;63(3):287-90. [Medline: 3473355] [doi: 10.1016/0030-4220(87)90191-5]

26. Agthong S, Huanmanop T, Chentanez V. Anatomical variations of the supraorbital, infraorbital, and mental foramina related to gender and side. J Oral Maxillofac Surg. 2005 Jun;63(6):800-4. [Medline: 15944977] [doi: $10.1016 /$ j.joms.2005.02.016]

27. Song WC, Kim SH, Paik DJ, Han SH, Hu KS, Kim HJ, Koh KS. Location of the infraorbital and mental foramen with reference to the soft-tissue landmarks.Plast Reconstr Surg. 2007 Oct;120(5):1343-7. [Medline: 17898610] [doi: 10.1097/01.prs.0000279558.86727.5a]

28. Ulm CW, Solar P, Blahout R, Matejka M, Watzek G, Gruber H. Location of the mandibular canal within the atrophic mandible. Br J Oral Maxillofac Surg. 1993 Dec;31(6):370-5. [Medline: 8286291] [doi: 10.1016/0266-4356(93)90193-Z] 
29. Solar P, Frey G, Ulm C, Gruber H, Matejka M. A Classification of the intraosseous paths of the mental nerve. Int. J. oral max. Fac. Implant. 1994;9(3): 339-44.

30. Kieser J, Kuzmanovic D, Payne A, Dennison J, Herbison P. Patterns of emergence of the human mental nerve. Arch Oral Biol. 2002 Oct;47(10):743-7. [Medline: 12356506] [doi: 10.1016/S0003-9969(02)00067-5]

31. Sawyer DR, Kiely ML, Pyle MA. The frequency of accessory mental foramina in four ethnic groups. Arch Oral Biol. 1998 May;43(5):417-20. [Medline: 9681117] [doi: 10.1016/S0003-9969(98)00012-0]

32. Shankland WE 2nd. The position of the mental foramen in Asian Indians. J Oral Implantol. 1994;20(2):118-23. [Medline: 7869414$]$

33. Katakami K, Mishima A, Shiozaki K, Shimoda S, Hamada Y, Kobayashi K. Characteristics of accessory mental foramina observed on limited cone-beam computed tomography images. J Endod. 2008 Dec;34(12):1441-5. Epub 2008 Oct 11. [Medline: 19026870] [doi: 10.1016/i.joen.2008.08.033]

34. Naitoh M, Hiraiwa Y, Aimiya H, Gotoh K, Ariji E. Accessory mental foramen assessment using cone-beam computed tomography. Oral Surg Oral Med Oral Pathol Oral Radiol Endod. 2009 Feb;107(2):289-94. Epub 2008 Dec 13. [Medline: $\underline{19071039}$ ] [doi: 10.1016/j.tripleo.2008.09.010]

35. de Freitas V, Madeira MC, Toledo Filho JL, Chagas CF. Absence of the mental foramen in dry human mandibles. Acta Anat (Basel). 1979;104(3):353-5. [Medline: 484199] [doi: 10.1159/000145083]

36. Hu KS, Yun HS, Hur MS, Kwon HJ, Abe S, Kim HJ. Branching patterns and intraosseous course of the mental nerve. J Oral Maxillofac Surg. 2007 Nov;65(11):2288-94 [Medline: 17954327] [doi: 10.1016/j.joms.2007.06.658]

37. Alantar A, Roche Y, Maman L, Carpentier P. The lower labial branches of the mental nerve: anatomic variations and surgical relevance. J Oral Maxillofac Surg. 2000 Apr;58(4):415-8. [Medline: 10759122] [doi: 10.1016/S0278-2391(00)90925-X]

38. Pogrel MA, Dorfman D, Fallah H. The anatomic structure of the inferior alveolar neurovascular bundle in the third molar region. J Oral Maxillofac Surg. 2009 Nov;67(11):2452-4. [Medline: 19837316] [doi: 10.1016/j.joms.2009.06.013]

39. Arzouman MJ, Otis L, Kipnis V, Levine D. Observations of the anterior loop of the inferior alveolar canal. Int J Oral Maxillofac Implants. 1993;8(3):295-300. [Medline: $\underline{\text { 2225464] }}$

40. Bavitz JB, Harn SD, Hansen CA, Lang M. An anatomical study of mental neurovascular bundle-implant relationships. Int J Oral Maxillofac Implants. 1993;8(5):563-7 [Medline: $\underline{8112797]}$

41. Misch CE. Root form surgery in the edentulous mandible: Stage I implant insertion. In: Misch CE, editors. Implant Dentistry, 2nd ed. St. Louis: The CV Mosby Company; 1999. p. 347-370.

42. Kuzmanovic DV, Payne AG, Kieser JA, Dias GJ. Anterior loop of the mental nerve: a morphological and radiographic study. Clin Oral Implants Res. 2003 Aug;14(4):464-71. [Medline: 12869009] [doi: 10.1034/j.1600-0501.2003.00869.x]

43. Rosenquist B. Is there an anterior loop of the inferior alveolar nerve? Int J Periodontics Restorative Dent. 1996 Feb;16(1):40-5. [Medline: 8631609$]$

44. Kieser J, Kuzmanovic D, Payne A, Dennison J, Herbison P. Patterns of emergence of the human mental nerve. Arch Oral Biol. 2002 Oct;47(10):743-7. [Medline: 12356506] [doi: 10.1016/S0003-9969(02)00067-5]

45. Misch CE, Crawford EA. Predictable mandibular nerve location--a clinical zone of safety. Int J Oral Implantol. 1990;7(1):37-40. [Medline: 2103117]

46. Ngeow WC, Dionysius DD, Ishak H, Nambiar P. A radiographic study on the visualization of the anterior loop in dentate subjects of different age groups. J Oral Sci. 2009 Jun;51(2):231-7. [Medline: 19550091] [FREE Full text] [doi: 10.2334/josnusd.51.231]

47. Greenstein G, Tarnow D. The mental foramen and nerve: clinical and anatomical factors related to dental implant placement: a literature review. J Periodontol. 2006 Dec;77(12):1933-43. Review. [Medline: 17209776] [doi: 10.1902/jop.2006.060197]

\section{To cite this article:}

Juodzbalys G, Wang HL, Sabalys G. Anatomy of Mandibular Vital Structures. Part II: Mandibular Incisive Canal, Mental Foramen and Associated Neurovascular Bundles in Relation with Dental Implantology.

J Oral Maxillofac Res 2010 (Jan-Mar);1(1):e3

URL: http://www.ejomr.org/JOMR/archives/2010/1/e3/e3ht.pdf

doi: $10.5037 /$ jomr.2010.1103

Copyright (C) Juodzbalys G, Wang HL, Sabalys G. Accepted for publication in the JOURNAL OF ORAL \& MAXILLOFACIAL RESEARCH (http://www.ejomr.org), 22 December 2009.

This is an open-access article, first published in the JOURNAL OF ORAL \& MAXILLOFACIAL RESEARCH, distributed under the terms of the Creative Commons Attribution-Noncommercial-No Derivative Works 3.0 Unported License, which permits unrestricted non-commercial use, distribution, and reproduction in any medium, provided the original work and is properly cited. The copyright, license information and link to the original publication on (http://www.ejomr.org) must be included. 